\title{
Java Community Local Intelligence in Mitoni Tradition as A Medium for Covid-19 Pandemic Prevention
}

\author{
Wakit Abdullah Rais ${ }^{1}$, Prasetyo Adi Wisnu Wibowo² \\ Sebelas Maret University, Surakarta, Indonesia \\ $\left\{\underline{\text { wakit.a.rais_1460@staff.uns.ac.id }}^{1}{\left.\text {, prasetyoadiwisnuwibowo@staff.uns.ac.id }{ }^{2}\right\}}^{2}\right.$
}

\begin{abstract}
Today, modern society prefers things that are efficient and effective which at the same time also avoids wastefulness. Therefore, many objects that should be prepared for a ceremony are eliminated or reduced by considering their less meaningful functions. Sources of data in this study were the tradition of mitoni and informants/sources who have an understanding and knowledge about it in Surakarta. The sources in this study consisted of academics/lecturers (Siti Muslifah, S.S., M.Hum.), students (Muhammad Fajar), and the general public of Surakarta. Informants were taken using the purposive sampling technique based on certain criteria or considerations (criterion-based selection). The findings of this study revealed that the tingkeban or mitoni in the life of the Javanese people have a very good place, considering that its function is a prayer to ask for safety for the infant in the womb so that this ceremony will continue to be carried out properly. Specific matters related to traditional offerings that are very important in ritual ceremonies include praying earnestly and solemnly in the hope that the request will be granted by God Almighty; always remember and respect the ancestors so that their spirits live peacefully in the eternal realm and the events that are held have the blessing of the ancestors.
\end{abstract}

Keywords: covid-19, tingkeban, local intelligence

\section{Introduction}

Many Javanese people still adhere to Javanese traditions, especially the tingkeban tradition for mothers-to-be who are 7 months pregnant. This tingkeban procedure is believed to bring harmony, good luck, and fortune to the child whose safety is prayed for in the event. From this study, the mindset, world view, world view, and local wisdom system that the Javanese people have in the tingkeban tradition can be found so that they can be applied to avoid the Covid-19 pandemic.

Javanese language and culture in this paper are understood under Javanese customs that apply in Java with all the local wisdom they have. Besides, in this context, local wisdom is also understood as a "medium" of knowledge and practice that can be used to properly and correctly solve problems faced [1]. Thus, it is assumed that there are many interesting things to be discussed scientifically concerning the position of language in the broader socio-cultural context to promote and maintain cultural practices and social structures [2]. The phenomenon of Javanese expression in customs reflects its local wisdom and the demands of their life [3]. This study also describes the behaviours used to achieve the welfare of life which is reflected in 
verbal and nonverbal behavior, including ways of life, world views, and patterns of thought that are reflected in the knowledge system (cognition system) of Javanese society [4],[5].

\section{Research Methods}

\section{History of the Tingkeban Traditional Ceremony}

The tingkeban or mitoni ritual has been known for a long time. That said, there were a husband and wife named Ki Sedyo and Nyi Satingkeb. Nyi Satingkeb has given birth to nine children, but none of them live long. They became very sad and then ventured to face their king, namely Raja Jayabaya who had sharp feelings and came from the Kingdom of Kediri, East Java [6]. The just and wise Raja Jayabaya gave advice like a father to his son for both of them. This is proof that Raja Jayabaya, is a great king who is dignified and wholeheartedly cares for the fate of his subordinates, including the common people. Raja Jayabaya does not differentiate his position in terms of receiving reports or complaints from his subordinates.

The valuable advice for Ki Sedyo and Nyi Satingkeb is that they are required to do spiritual practice in that way they must purify themselves and pray fervently for all their wishes to God Almighty and the Most Holy. Ki Sedya and Nyi Satingkeb carried out the advice of the king of Jayabaya and fulfilled all the requirements and offerings that had to be provided. Ki Sedya and Nyi Satingkeb finally managed to get long-lived offspring.

This qualitative descriptive study aims to describe local intelligence in Javanese culture regarding "the safety of seven months pregnant women" in Surakarta [7],[8]. Therefore, this culture of mitoni still survives in society and contains a noble message for its supporters. Research data includes verbal data (terms, expressions, other language units) and nonverbal (symbols, symbols, offerings) primary and secondary data sources [9]. Research data collection was carried out using in-depth interview techniques and participant observation under the provisions of the ethnographic method [10],[11]. The validity of the data is maintained through triangulation techniques (methods, theories, researchers, data) [12],[13].

\section{Results and Discussion}

\section{The Preparation of Tingkeban}

Modern society today prefers things that are efficient and effective and do not waste money or be extravagant. This makes a lot of objects that should be prepared for a ceremony to be reduced or even eliminated by considering their function which is considered less meaningful. The tingkeban tradition is carried out for mother-to-be who is pregnant for the first time with a gestational age of 7 months. For the second pregnancy, the tingkeban or mitoni ceremony is no longer held. The preparations and meanings contained in the tingkeban or mitoni customs are as follows. The sources in this study included academics/lecturers (Siti Muslifah, S.S., M.Hum.), Students (Muhammad Fajar), and the general public of Surakarta. Informants were taken by purposive sampling technique based on certain criteria or considerations (criterionbased selection) [14].

\section{Offerings in the Tingkeban tradition}

Offerings are also commonly referred to as symbols. This means that every object given for offering or almsgiving is interpreted as the value contained in it according to the ability of the 
offering object and can also be linked through the name of the object of sacrifice. For example sugar cane means anti-ulcer. The sugar cane used for offerings is yellow sugar cane or rejuna sugarcane. Sugarcane of this type is defined as sugarcane with sweet quality, clean because it is yellow, and has more content.

The offerings also function as a repellent for reinforcements or disturbances from unwanted things that are required in the tingkeban traditional ceremony. The offerings used in the tingkeban tradition are as follows:

1) Sekar Setaman

Sekar setaman means setaman flower. Sekar Setaman consists of roses, jasmine and cananga flowers. The three flowers are selected flowers that are considered the king or queen of flowers.

2) Pengaron

3) Pengaron is a place for Perwita Sari. Perwita means holy, while sari means flower. Pengaron is filled with holy water that has been mixed with other fragrant flowers. This symbolizes that everyone (especially those who are pregnant) must always purify themselves, both physically and mentally.

4) Toya suci

5) This toya suci or holy water is used to bathe the mother-to-be which is taken from seven springs which is adjusted to the age of the future mother's womb, which is seven months. The seven types of water are taken from the seven cardinal directions or water sources (wells).

6) Nyamping

The word nyamping means using the seven jarit (Jarit is a fabric which is worn by Javanese where the function is to cover the body to the legs) in turn. Those who use it are pregnant women with a gestational age of 7 months, which is the center of the mitoni tradition. The seven fabrics are chosen and have various motifs whose overall motifs can be interpreted as having a good meaning, including dringin, lasem parangkusuma, sidamukti, sidaluhur, truntum, and udanriris.

7) Keris

8) The father-to-be in this ceremony wears a keris named Kyai brojol. The hope is that the baby will be born smoothly or mrojol (Javanese). This keris is usually used to cut yellow coconut leaves during luwaran. At the end of this keris, turmeric is planted as a symbol of the elimination of harm (sukerta, Javanese) and all diseases (reject logs). Turmeric is a representation of all forms of empon-empon which are commonly used as ingredients to make herbal medicine aimed at eliminating various diseases according to the type of ingredients.

9) Dhingklik

Dhingklik is a small chair where the mother-to-be sits. On top of the dhingklik are placed various kinds of leaves, such as kluwih leaves, weeds, and kappa-kappa leaves. Everything is wrapped in a base class.

10) Ndhog

Ndhog means egg. Usually, the egg used in this tradition is chicken's egg. Chicken eggs are used in the part of brojolan (when a baby comes out from the womb). The egg consists of two parts, namely the yolk as a symbol of blood and the white as a symbol of amniotic fluid.

11) Cengkir gadhing

Cengkir Gadhing is a young yellow coconut. The size of this young coconut is usually smaller than other coconuts. This is described as Kamajaya and Dewi Kamaratih who are 
very famous puppet characters who have handsome and beautiful faces. This implies that if the baby is born a boy, it is expected to have a handsome and dignified face like the Kamajaya, while if the baby is born a girl, it is expected that the beauty is like Kamaratih.

12) Siwur

Siwur is a dipper made from coconut or coconut shells whose meat that have already been taken. This shell is given a hole at the bottom which is useful for water out. In Javanese, siwur means ngaisi sing ana ing dhuwur (filial piety above).

13) Klenthing

Klenthing in this tradition is a symbol of pregnancy and water as a symbol of amniotic fluid (a crater in the birth process). Klenthing is useful for closing the event after the event is over.

\section{Implementation of the Tingkeban Ceremony}

1) Siraman

Siraman is a form of culture that has a very good purpose, namely to clean a mother-to-be who is pregnant with her baby. The hope of this siraman is of course not only meaningful for the mother but also contains the hope that her child will also become a person who has a clean and good physical and spiritual mind. The ceremonial procession and actions performed in the ceremony according to Beltaljemur Adammakna:

Kang ngarbini disirami, dene aduse nganggo siwur kang isih ana kambile (kambile ora dicukil), aduse nganggo banyu sekar setaman (banyu didekeki kembang). Dikosoki glepung beras mancawarna (warna 7) diwori mangir pandan wangi lan godhong kemuning, nang ngedusi dhukune utawa sanak sadulure. Dhene lungguhe ing dhingklik dilemeki: klasa lan godhong-godhongan: apa-apa, kluwih, karu, dhadhapserep, alang-alang lan lemek kang bangsa sambet yaiku: letrek, jingga, banguntulak, sindur, sembagi, slendang lurik puluh watu yuyu sekandhang lan lawon.

Meaning: pregnant women are bathed using a dipper made of coconut fruit (coconut shells that still have coconut meat), bathing using water mixed with flowers (sekar setaman), cleaned with seven colors of rice flour, mixed with fragrant pandanus and yellow leaves. are parents or siblings. When a pregnant woman is bathed, she sits on a chair with a base in the form of leaves: opo-opo leaves, kluwih, kara, dhadap serep, thatch, and lemek (mat), which are in the form of sabet, namely: lepret, orange, bangun tulak, sindur, sembagi, shawl and white lurikuluh watu yuyu cloth.

In practice, clear water is used as a sign that clean water is a cleanser from dirt that sticks to the body or us. Water is taken from seven sources with the intention of teaching that water as the source of our life does not only come from one place. This implies that in the future, babies will get blessings from various sources of life, even though getting them may encounter obstacles and difficulties.

There is a teaching in the world of Javanese philosophy that humans who live in this world are given education not only since they are born, but also when they are still in their mother's womb. Through this ceremony, it is hoped that children can also get education about personal hygiene, both physically and mentally. This spraying activity is usually carried out in the morning when someone is cleaning herself to take a shower. To carry out this event, a special area is created which served to show visitors that the mother-to-be had been purified. If a large enough room is not available, then a bathroom can be used for this activity.

Parents-to-be are prohibited from wearing jewelry during the siraman ceremony and are not allowed to wear white clothes. This is intended so that the mother-to-be is clean from 
worldly life because at that time she is carrying out a request to God Almighty with a whole clean heart.

The mother-to-be sits on a chair covered with an old mat with the intention that humans must work according to their abilities and live simply, not luxury because being a rich person does not mean that his wealth will be able to bring her to the Almighty properly. The motherto-be bathing or spraying process is carried out using a jug filled with water taken from seven springs. After the bathing process or often called siraman, the meaning can be taken is as follows.

a. Parents are good role models for future babies.

b. Humans have received teachings from the womb.

c. To purify yourself or clean yourself, of course, you have to prepare a place and clean water too.

d. Seven springs can provide clues for humans to seek the source of life with all their might and strength, even though difficulties may stand in their way.

e. It is not natural if when you purify yourself, you should still use jewelry that is characterized by luxury.

f. Humans are expected to find and give color and fragrance to life-like flowers.

g. Parents always have hopes that their baby will get the best from every human being who loves them.

h. Humans were created from the ground and will return to the ground because nothing is eternal in this world.

\section{2) Dandanan}

There are seven types of cloth used in this mitoni ceremony which are the cloth of choice. Previously, the mother-to-be wore a batik cloth or kemben. Wearing clothes in this case, of course, must be able to be placed according to the conditions and situations. All clothes are fine, but of course the right clothes and used at the right time and place are a major consideration. The seven batik cloths are provided to be tried on one by one and judged which one is the most suitable for mother to-be who are waiting for the birth of their baby.

The rope made of woven coconut leaves and the thread tied to the mother-to-be is cut by the father with a keris. This illustrates that a person will start a new responsibility as a father and mother because of the birth of a child who has been eagerly awaited in this world and is released from the umbilical cord that connects the baby's life with its mother. A father is also expected to be able to protect and face the obstacles his family will face. It is the duty of a father as the head of the family to be responsible for the safety and happiness of his family. After cutting the rope, the father walked back three steps then turned and ran. This is so that the baby who will be born has comfort and smoothness.

Brojolan comes from the word mbrojol which means coming out of the mother's womb. The brojolan ceremony is an illustration of the parents' hopes that it will be provided with ease and smoothness during the labor process later. Coconut ivory is the fruit used in the tingkeban event. Ivory coconut was chosen because it has a clean yellow color. There are two ivory coconuts used in this ceremony which depict the Dewa (God) Kamajaya and Dewi (the goddess) Kamaratih. This coconut explains that parents have the hope that the child born will have a handsome face and noble character like Dewa Kamajaya and beautiful like Dewi Kamaratih. 


\section{3) Angreman}

For Javanese people, hens are a good example of caring for their children. The hen is very aware and patient and understands its duty to provide body warmth to the eggs that have been released. The lesson that can be learned from the Angreman ceremony is that the mother-to-be is expected to be strong, patient, and able to give love, attention, and caution in dealing with her pregnancy. Because, in the body or the mother's stomach, there are humans to-be who will continue the lineage. This period of pregnancy must be faced together with the father-to-be who needs to protect and provide for all the needs of his wife and to maintain the togetherness between them.

\section{4) Meaning of the Tingkeban Ceremony}

Meaning and Function of Tingkeban in the View of Javanese Society. Tingkeban or mitoni in the life of the Javanese community is still, considering that the function of this event is as a prayer to ask for safety for the infant in the womb. Specific matters related to traditional offerings that are very important in ritual ceremonies are as follows:

a. By praying earnestly and solemnly, it is hoped that the request made will be granted by God Almighty.

b. To always remember and respect their ancestors so that their spirits live peacefully in the eternal realm and bless the ceremonies held.

c. The tingkeban ceremony is held with the hope that the mother and future baby will always have safety and success.

d. Offerings have meaning and value as a form of asking for blessings so that they are kept away from all disturbances and temptations of spirits and as a request to the Almighty to be kept away from bad luck and heavy trials.

e. Siraman means to clean themselves in the hope that no evil creature can bother them considering they like something dirty.

\section{Conclusion}

Local wisdom in the Javanese culture of pregnant women in Surakarta is interesting to study. This is because, from a health perspective, there are many noble values contained in Javanese cultural events that need to be scientifically presented. The actuality of the mitoni ceremony in the life of Javanese society in Surakarta can be identified empirically considering that this ceremony is still being held today. Especially for people who are still loyal to Javanese (ancient) culture where they still maintain the norms of Javanese ancestral traditions.

In the mythic tradition, various ubarampe and procedures turned out to be able to prevent the Covid-19 pandemic. The message of the ancestors of the Javanese people is that through the media, this ceremony is a symbolic means of mitony with the main goal being to achieve salvation and blessings from God Almighty. In the implementation of tingkeban, there is a message to always maintain one's health and safety. This is the essence of a healthy life that can be used as a means of prevention to avoid Covid-19.

\section{References}

[1] Ahimsa-Putra, Heddy Shri. 2007. Ilmuwan Budaya dan Revitalisasi Kearifan Lokal. Tantangan Teoretis dan Metodologis. Pidato Ilmiah Dies Natalis FIB UGM ke 62 di Yogyakarta. Yogyakarta: Gadjah Mada University Press. 
[2] Foley, W. A. 1997. Anthropological Linguistics An Introduction. University of Sydney: Blackwell Publishers.

[3] Komonthip Kongprasertamorn (2007) tentang "Local Wisdom, Environmental Protection and Community Development: The Clam Farmers in Tambon Bangkhunsai Phetchaburi Province Thailand" dalam Manusya: Journal of Humanities 10.1, 2007.

[4] Edi Subroto, D., dkk., 2003, "Kajian Etnolinguistik Terhadap Paribasan, Bebasa, Saloka, Pepindhan dan Sanepa", Laporan Penelitian, Surakarta: Program Pascasarjana Universitas Sebelas Maret.

[5] Hartini. 2011. "Kajian Gender dan Pendidikan Wanita pada Sastra Wulang dalam Naskah Jawa".

[6] Disertasi. Surakarta: Universitas Sebelas Maret.

[7] Wakit Abdullah. 2013. "Kearifan Lokal dalam Bahasa dan Budaya Jawa Masyarakat Nelayan di Pesisir Selatan Kebumen (Sebuah Kajian Etnolinguistik)", Laporan Penelitian untuk Disertasi, Surakarta: Universitas Sebelas Maret.

[8] Edi Subroto, D. 1992. Pengantar Metode Penelitian Linguistik Struktural. Surakarta: Sebelas Maret University Press.

[9] Sudaryanto. 1993. Metode dan Aneka Teknik Analisis Bahasa:Pengantar Penelitian Wahana

[10] Spradley, James P. 1997. The Ethnographic Interview. Diterjemahkan oleh Misbah Zulfa Alizabeth dengan Judul Metode Etnografi, Yogyakarta: Tiara Wacana.

[11] Na Talang, Ekavit, 2001. Local Wisdom in the Process and Adaptation of Thai People. 2nd ed. Bangkok: Amarin.

[12] Phongphit, Seri, and Wichit Nantasuwan, 2002a. Master Community Plan: People Research and Development. Bangkok: Charoenwit.

[13] Phongphit, Seri, and Wichit Nantasuwan, 2002b. The Learning Process to Sustainnable Develepment. Bangkok: Charoenwit.

[14] Sutopo, H.B. 2006. Metode penelitian Kualitatif. Surakarta: Sebelas Maret University Press.

[15] Siti Muslifah. 2012. "Fenomena Androginik Perempuan Jawa dalam Perspektif Lokal dan Global", Makalah, dalam Prosiding Hasil Seminar Internasional Preservation and Development Strategies for local Wisdom in The Global Frame Work, pada tanggal 11 oktober 2012 di Fakultas Sastra dan Seni Rupa Universitas sebelas maret Surakarta. 